\author{
ALBERT GUZIAK \\ ORCID: 0000-0001-8748-624X \\ Uniwersytet Warszawski \\ a.guziak@uw.edu.pl
}

\title{
The (ambivalent) far-right populist stance on the European Union with the example of the Austrian party FPÖ
}

\begin{abstract}
This article explores the attitude towards the European Union represented by right-wing populist parties by the example of the Austrian Freedom Party. Due to the advanced stage of the European integration and a multitude of its positive and negative repercussions, far-right populist parties adopted an antagonistic rhetoric aiming at discrediting and limiting the influence of the EU in a country, they represent. The FPÖ skillfully shapes a Euro-sceptic discourse in Austria, embracing a populist strategy of manipulation and hostility. The populist itself is, however, far from offering a clear political vision. Based on the reflections on populism by Ernesto Laclau, elaborating on the far-right populist strategies of a former FPÖ's leader Jörg Haider and finally confronting the party discourse with real political actions, this article constitutes an attempt to show the complexity of a mutual relation between populism and the European Union.
\end{abstract}

Keywords: European Union, Euro-sceptic, far-right, Freedom Party of Austria, populism.

\section{Introduction}

"Mehr Österreich, weniger EU"1 — more Austria, less EU. This political slogan in the official party program gave the Austrian far-right populist party FPÖ Freiheitliche Partei Österreichs (Freedom party of Austria) — its tone of an official discourse on EU matters during the latest EU Parliamentary campaign. The Eurosceptic focal point of political strategy corresponds to the present ideological

${ }^{1}$ See: Mehr Österreich, weniger EU [Party program of FPÖ, trans. A.G.], https://www.fpoe. eu/mehr-oesterreich-weniger-eu/ (accessed: 24.03.2020). 
concepts of European right-wing populist parties stressing the necessity of undermining the influence of the European Union or disbanding this organization in its present form, making it one of the enemies of so-called ordinary people. Unlike some other anti-EU populist parties in Europe, the Freedom Party of Austria has been in government for almost the last two years (from 2017 till 2019), thus having the genuine opportunity to confront its ideological approach towards the EU with real politics. The outcome of this set-up is far from being clear and unequivocal.

While attempting to define the true stance on the European Union and European integration itself for far-right populist parties, I first make an attempt to clarify the phenomenon of populism in general and its complexity, including the root causes in the form of European economic and cultural processes which have accelerated the antagonism characterizing the populist discourse (particularly that of a right-wing kind) on EU issues. This part will constitute the first chapter of the present paper. The second part will deal with the presentation of key points in history, prominent figures and ideology of the Freedom party of Austria by focusing on the attitude towards the European Union. In the third chapter, I will analyze the official discourse of the FPÖ when it comes to European politics and confront it with real politics. In this part, I would like to bring forward some Austrian-specific factors presented by the right-wing Freedom party in its rhetoric and show them in the particularity of far-right populism with regards to the EU. The final chapter will give a conclusive idea on the topic of this paper by summarizing its precedent parts and placing them in one context.

\section{Populism in relation to European integration processes}

The term populism is not precise, and there is neither general consensus on one definition nor one which has been forged through academic writings in the area of political sciences, specially related to the theory of democracy. What might appear to us as populist, adopted by political parties, even mainstream ones, mostly for opportunistic and short-term motives, is not necessarily populism, but it can be defined as an occasional political strategy appealing to the 'people' or 'ordinary people' because the invocation of 'people' in the political discourse is the cornerstone of populism, whether we call it ideology or political strategy, following the Latin root of populism - populus meaning 'the people' or 'the folk'. For the purpose of this paper, I will utilize the definition of populism by Ernesto Laclau one of few theorists and thinkers on that phenomenon. The foundation for Laclau's political reflections was laid by European post-structuralism and post-Marxist philosophers/linguists, such as De Saussure, Derrida and Lacan. The concept of deconstructing the discourse and the approach of rejecting the idea of interpreting text or world within pre-established socially-constructed structures vastly contributed to bring populism out of political reasoning entrenched in bipolarity between 
right and left, and to oppose it with social, political and discursive occurrences. His opus magnum on populism, On Populist Reason, presents an analysis of concept and practice of populism. As James Hodgson noted:

It is motivated by Laclau's suspicion that the dismissal of populism is somehow involved with 'the dismissal of politics tout court, and the assertion that the management of community is the concern of an administrative power whose source of legitimacy is a proper knowledge of what a 'good' community is. ${ }^{2}$

This assertion will come to the fore in the next part of this chapter while analyzing European processes in the context of populism. Laclau holds the view that what he calls a 'populist logic' exists in every society and is strongly linked to the permanent process of establishing its identity. Laclau finds, therefore, that the academic search for one satisfactory global interpretation and definition of populism is counterproductive. He claims:

Populism has no referential unity because it is ascribed not to de-limitable phenomena but to a social logic whose effects cut across many phenomena. Populism has no definite political program, therefore, but is a manner of articulating unfulfilled demands and creating solidaristic communities. It is, quite simply, a way of constructing the political. ${ }^{3}$

Populist parties demonstrate more adaptation to the dynamism of social and political processes than mainstream parties. The Populist focal point and lasting storyline is the juxtaposition of a (degenerate) 'political class', 'elite', or 'establishment', and 'the people', the sole genuine voice of whom a populist party perceives itself to be. The populists, therefore, express strong approval of direct democracy, calling themselves the true advocates of democracy, even if they use it instrumentally and chose only those democratic elements they need for their political purposes. When it comes to right-orientated populism, a pertinent perspective is given by Thomas Greven, who claims:

Right-wing populism adds a second antagonism of 'us versus them' to this constellation as well as a specific style of political communication. Firstly, based on a definition of the people as culturally homogenous, right-wing populists juxtapose its identity and common interests, with are considered to be based on common sense, with the identity and interests of 'others', usually minorities such as migrants, which are supposedly favored by the (corrupt) elites. Secondly, right-wing populists strategically and tactically use negativity in political communication. ${ }^{4}$

Populist political groups with far-right ideologies, including the Austrian FPÖ party, construct their identity upon hostile and manipulative rhetoric towards enemy figures who apparently represent a threat to ordinary people and obviously are

${ }^{2}$ On populist reason by Ernesto Laclau, reviewed by James Hodgson, https://marxandphilosophy.org.uk/reviews/16457_on-populist-reason-by-ernesto-laclau-reviewed-by-james-hodgson/.

3 E. Laclau, On populist reason, London-New York 2005, p. 6.

${ }^{4}$ See: T. Greven, The rise of Right-Wing Populism in Europe and the United States - a comparative perspective, p. 1, https://www.fesdc.org/fileadmin/user_upload/publications/RightwingPopulism.pdf (accessed: 28.03.2020). 
made up in order for the populists to portray themselves as defenders of the nationalist 'law and order', which is threatened by supposed excessive powers from the cultural and intellectual elites or international or European institutions. Such language, based on fear-mongering and manipulation, appeals to the conservative, communitarianism-oriented and antimodernist electorate, which has always constituted a substantial part of every society. We have to also acknowledge the fact that, due to rapid globalization and Europeanisation, each society is embroiled in a permanent turmoil of changes, anxieties and tensions resulting from those processes. The European integration process, interlaced with the globalization, implies, as the former member of the European Commission Ralf Dahrendorf notes, economic growth and prosperity, but it also stands for competitiveness, raging capitalism and the remodeling of social cohesion.

To stay competitive in a growing world economy are obliged to adopt measures which may inflict irreparable damage on the cohesion of the respective civil societies. If they are unprepared to take these measures, they must recur to restriction of civil liberties and of political participation bearing all the hallmarks of a new authoritarianism [...]. The task for the first world in the next decade is to square the circle between growth, social cohesion and political freedom. ${ }^{5}$

This perspective, shown by Dahrendorf, seems to accurately reflect the relationship and intricacies between economic processes and the popularity of the populist discourse gaining ground in European countries. The right-wing populist parties have made the European Union a scapegoat for many misfortunes (true or alleged) befalling European countries, as a kind of 'whipping boy'. The ultimate goal of the populist opposition to the European integration project is to build up a leading political position and power in domestic policy. Expanding on Dahrendorf's reflections, we can single out the economic and cultural aspects of the European integration which pave the way for the rise in populism. The EU economic policies favor the pressure of competitiveness between EU member states, which may lead to a deterioration of socio-economic conditions for many work branches and unbalance the instruments of social protection on the side of each member state whose efforts towards a fair redistribution of merciless single-market processes and alleviation of harsh rules of competition may fail, due to strict EU regulations on which state aid and redistribution maneuvers a state or local administration are allowed to employ. The distance of an average European citizen from the decision-making center in Brussels, and the incomprehension of economical processes, coupled with a failure to accentuate the benefits of the European integration outweighing the negative results from the perspective of mainstream political forces create a Pandora's box which the populist parties are likely to open. According to Buti and Pichelmann, "similarly, a number of elements fuel anti-EU sentiments

5 See: R. Dahrendorf, Economic Opportunity, Civil Society and Political Liberty, p. 4, https:// www.unrisd.org/80256B3C005BCCF9/(httpAuxPages)/AF2130DF646281DD80256B67005B66F9 /\$file/DP58.pdf (accessed: 28.03.2020). 
from a native-identity perspective. Accusations of 'homogenisation' undermining or even erasing national specifics and identity are commonly brought up by populists mainly on the right side of the political spectrum." For conservative and nationalist electorates, the delegation of a vast spectrum of institutional competencies to the EU bureaucratic apparatus, together with a deficit of transparency in the decision-making process, is perceived as an attack on national independence, which is easily fueled by the populist emotional and antagonistic discourse. This mutual interdependency follows Laclau and his thoughts on populism, which, in his view, results from reducing politics to the management of a state without exploring the social and economic processes which may articulate themselves in unfulfilled demands from the people. The Freedom Party of Austria adroitly uses this complexity in its political activity.

\section{History and ideological foundation of FPÖ}

"The Freedom Party of Austria (FPÖ) was founded in 1956 as a Germanic national liberal party with close associations to the Nazis. Its first two chairmen were former SS officers: Anton Reinthaller (1956-58) and Friedrich Peter (195878)." " Since its inception, the party has not shown one single streak of ideological grounds, but rather switched from a far-right to a center-orientated and pragmatic party until the 1980s, when it became a far-right and anti-elite force. In the 1990s, the party recorded its first major successes on the Austrian political scene and this factor is mainly attributed to its most prominent leader ever, Jörg Haider, whose impact on the advance of far-right populism in Austria and in other countries is invaluable. It was he who 30 years ago as the first populist leader got the feeling that fear-mongering is a powerful tool to obtain success in elections. Furthermore, he first realized that arousing permanent attention in the media whilst not putting up any real problems for discussion will effectively increase the fear itself. As one of the most prominent German political magazines, Süddeutsche Zeitung, noted:

When US President Trump makes a decision that is particularly unpopular for the EU, he usually explains it in two words: "America First". He warmed up a slogan that Jörg Haider had already coined in 1992. Haider's xenophobic populism began with the 'Austria first' referendum. Haider had been chairman of the FPÖ for six years. Up to this point he had made headlines as a newcomer who was not afraid of taboos and confused Austrian domestic politics. With that he got more and more votes, but he didn't become a big player. That changed in the early 90s. Due to the fall of the Berlin Wall, the Gulf War and the Balkan Wars, hundreds of thousands of refugees came to Austria within a few years. Haider was the only one to sense

${ }^{6}$ M. Buti, K. Pichelmann, European Integration and populism: Addressing Dahrendorf's quandary, p. 4, https://ec.europa.eu/info/sites/info/files/jan2017-populism.pdf (accessed: 28.03.2020).

7 See: Austria's FPÖ Freedom Party: A turbulent history, https://www.dw.com/en/austriasfp\%C3\%B6-freedom-party-a-turbulent-history/a-48789817 (accessed: 2.04.2020). 
the increasing skepticism of many Austrians towards the "strangers" - and that he could use them to his advantage. ${ }^{8}$

The FPÖ achieved its greatest political triumph in 1999, when it obtained $26.9 \%$ of the vote in Austrian parliament elections. The party, at that time led by Jörg Haider, concluded a coalition agreement with the Austrian People's Party (ÖVP - Österreichische Volkspartei), and together they set up a government. This alliance was the first in history since the end of World War II in which a political force tainted by Nazi origins technically came into power. Haider's zeal and political intuition were the foundation for this remarkable success of a far-right populist party which paved the way for the growing popularity of populism in our times. During the 'Austria first' election campaign around refuges and foreigners, he developed the right-wing populist discourse that was eagerly elaborated on and amplified in 2015 when Europe faced the gravest refugee crisis in modern times. Similarly to Haider in the early 1990s, all European right-wing populists, from Marine Le Pen to Matteo Salvini and the German AfD, were betting on the refugee issue - and they achieved election successes in many places.

The coalition deal triggered an unprecedented response from the European Union. Portugal, then holder of the EU's rotating presidency, said the other 14 EU states would refuse bilateral contacts with Vienna, not back any Austrian candidate seeking a position in an international organization and only receive Austrian ambassadors "at a technical level" if the FPÖ joined a new government in Austria. Because the FPÖ had received a larger share of the vote than the ÖVP, Haider had been in line to become Austrian chancellor. But strong international pressure convinced both parties to give the chancellor post to the ÖVP. Haider stepped down as FPÖ chief in February $2000 .^{9}$

Nevertheless, this new political situation upset and shocked European leaders. Haider's sudden death definitely cast a damper on FPÖ's ambitions and zeal for subsequent electoral victories, but Haider's legacy in the form of perfected far-right populist strategies turned out to be timeless. According to Süddeutsche Zeitung:

It is one of the central tactics of right-wing populists to 'excite' the media. Haider was the first to perfect this in Europe especially because of his strong verbal provocations. In 1995, Haider claimed in ORF that the "Waffen-SS was part of the Wehrmacht and that it therefore deserves all honor and recognition". There was also great outrage in 1991, according to his statements about the employment policy of the Third Reich: "Well, that didn't happen in the Third Reich, because in the Third Reich they did a decent job policy, which doesn't even bring your government together in Vienna. You have to say." Haider said things like that to provoke - but also to keep the flank to the radical right open. ${ }^{10}$

${ }^{8}$ See: Der Mann, der den modernen Rechtspopulismus erfand [trans. A.G.], https://www. sueddeutsche.de/politik/10-todestag-von-joerg-haider-der-mann-der-den-modernen-rechtspopulismus-erfand-1.4156739 (accessed: 2.04.2020).

9 See: Austria's FPÖ Freedom Party.

10 See: Der Mann, der den modernen... 
It is typical for far-right populist parties to not openly declare themselves as extreme-right or nationalist in order not to evoke a negative connotation nor to become an easy object of stigmatization; - a crafty juggling and flirting with all parties of a right and conservative spectrum is more common. Haider's tactical approach of being perceived as an anti-elite voice of the people later found many followers all over Europe. Haider deliberately portrayed himself as a politician who was always sympathetic to the ordinary Austrians and who, as an ordinary fellow, opposed the dominance of the major SPÖ and ÖVP parties. He coined a credible slogan: "gegen die Privilegien von denen da oben" - against the privileges of those up there - although, of course, he himself was 'one of those up there'.

Haider's contribution to the success of right-wing populist parties fell on fertile ground after 2015, when Europe was struck by a considerable wave of refugees and asylum seekers and was still not recovered from a Euro zone crisis, and where the whole idea of European integration and the unique positive economic consequences began to be questioned. FPÖ made use of those contributive factors in 2017 during the election campaign for the Austrian parliament. Former leader Heinz-Christian Strache at that time adopted an abrasive and populist discourse based on anti-immigrant, anti-foreigner and, by extension, anti-European, slogans. The hardline political message even caused the mainstream conservative ÖVP to use more virulent language. The parliamentary election of 2017 resulted in the formation of a second governmental coalition between the mainstream ÖVP and, again, the right-wing populist FPÖ. However, the cooperation lasted less than two years, as in May 2019, German magazine Der Spiegel revealed that the FPÖ's president Strache was directly involved in a corruption scandal, which eventually put an end to the FPÖ's participation in Austrian government. Nevertheless, the election campaign of 2017 and the coalition government gave a unique opportunity to compare the discursive strategies in the campaign around the European Union which FPÖ employed, and the real political actions the party undertook in EU matters, all while being in government and in possession of true instruments of power.

\section{FPÖ's attitude towards European Union (rhetoric vs. real politics)}

The official rhetoric (presented in the official party program) is based around a consequential logic: firstly, the party refers to a fragment of an interview with the ex-president of the European Commission, Jean Claude Junker, who points to a supposedly obscure and centralistic mechanism of decision making within EU institutions. As we read in the program: "We decide something, then put it under discussion and wait for a while to see what happens. If there is no big shouting and no riots because most people do not understand what has been decided, then 
we go on - step by step until there is no going back." In fact, this fragment is disjointed from the context of the whole article from German magazine Der Spiegel. Mr. Junker stresses the complexity of legislation at the EU-level and, considering the entire text, it more accurately exposes, if such is the case, member states' lack of accuracy and diligence as far as EU decision-making is concerned. The FPÖ used the interview to dismiss the European decision process as 'Brussels' system'. The party links this term to Brexit, which, in their view, was an outcome of the alienation of the British people from that 'Brussels' system' and the immense centralization of EU bureaucracy; they also blame it for triggering the so-called 'refugees' crisis' of 2015.

What they propose at the core of their program is a classic populist manifesto of far-right parties regarding nation vs EU relationships, including such slogans as: community of free and sovereign nations (which you can easily find in the Italian Lega, the French RN or the German AfD), strong opposition to a European super state, accentuation of the subsidiarity and proportionality principle when it comes to the division of competencies between member states and the EU organs, reduction of EU officials (which might be worth considering), and defense of freedom and sovereignty. The last point is particularly expounded upon by the FPÖ, alleging (without providing any precise explanation) that EU policies will allegedly burden Austria's alleged excellent social security system, which may no longer provide the highest standard; strain the national budget by increasing the financial contributions to the common budget following Brexit; impose an EU-wide tax; create one single Euro zone finance minister; and, finally, will upset Austrian military neutrality (just as a reminder, in 1955, Austria signed a declaration of eternal neutrality, prohibiting it from joining any military alliances, which put an end to the post-war occupation of Austria). You will not find in the party discourse an explicit and unequivocal reference to advocating Austria's exit out of the European Union, neither can any proposition to officially disband the organization be traced; nevertheless, the discourse clearly denotes an antagonistic and anti-European attitude from the FPÖ. Right-wing populist parties, including the Austrian Freedom Party, are not inclined to call for leaving the EU in their respective countries (Marine Le Pen the leader of the former French Front National once urged the French people to say goodbye to unified Europe, but backed out of this idea eventually, proposing a profound reformation of the EU instead by opting for a 'Europe of Nations'). Doing so, they would easily become the object of attacks from the side of pro-European political forces; given the fact that according to the Eurobarometer survey of 2019, around $67 \%$ of all EU-citizens approve of their countries' membership in the EU (in Austria, $60 \%$ of the entire population is pro-European), an overt political slogan to leave the European structures would politically be a double-edged weapon.

Evidently, one will not find in the FPÖ's discourse on EU matters any key words or references to positive connotation; it never puts Austrian membership in the EU in a broader context, showing indications of the benefits of membership 
for ordinary Austrians which outweigh any negative repercussions - the balance of advantage and disadvantages for Austria is well laid out in an official governmental report: 25 Jahre EU-Mitgliedschaft Österreichs - eine Bilanz aus wirtschaftlicher Perspektive - '25 years of Austrian EU-membership - a summary from an economic viewpoint'. Instead of a more neutral and varied approach towards EU issues, the populist FPÖ primarily focusses on exploiting the supposed threat Brussels poses to Austrian self-governance and the 'ordinary people'. As the discourse is a combination of language and a social context, the language itself or the political language is the main and the most powerful vector of political activities; therefore, the FPÖ's aforementioned anti-EU rhetoric skillfully operates linguistic tools such as: figures of speech/hyperboles: (Aushöhlung und Überforderung des erstklassigen österreichischen Sozialsystems — "hollowing-out and overloading of the first-class Austrian social system"), ...nur die europäische Umverteilungsbürokratie aufblähen würde (speaking of a single European tax: "it would only inflate the European redistributing bureaucracy," etc.). An especially popular linguistic means for the populist is the argumentum ad populum, which is an emotively-laden rhetoric figure widely used in ancient times, prefiguring a statement/ conclusion which is not proven by any arguments but rather reduces its veracity to the feelings or beliefs of closely undefined ordinary people. FPÖ's analyzed official party program repeatedly refers to Austria or Austrian, covering the crucial subjects of the social security system, money (EU budget), safety, independence, etc. Much attention is also drawn to the British people, who, in the view of the party, finally opposed the 'Brussels system'. The aforementioned linguistic instruments are vital for creating a specific rhetoric, as they are designed to describe a phenomenon with emotional and picturesque words which can be easily remembered by potential voters. In general, the outlined party rhetoric about the EU is built on false information or instrumental interpretation, which is nothing new to the whole national-populist discourse gaining ground all across Europe.

Nevertheless, over the last two years as a coalition partner in the government with ÖVP, the FPÖ never used its position to sabotage the implementation of EU laws (just as a reminder, FPÖ politicians held strategic posts of minsters of defense, interior and foreign affairs, including the former leader Heinz-Christian Strache as Vice-Chancellor), giving way to the 'Brussels system', fulfilling Austria's obligations to the European community flawlessly, acting, in fact, as a mainstream pro-European force. Surely, we cannot ignore the fact that the centrist pro-European party ÖVP was the leading political force in the Austrian government, yet still Austria performed its half-year presidency in the EU in 2018 as an exemplary pro-European force without being gnawed away by the anti-EU co-government figure. As we all remember, Austria even exerted pressure to carry out legal proceedings against the Polish government in the case of infringement of rule of law principles. Following the inauguration of the new Austrian government, former FPÖ leader Heinz-Christian Strache softened the official party anti-EU rhetoric, 
claiming to stand by the European Union, and by the European peace project. As we can read in the journal Politico: "The Freedom Party's position on Russia is also full of contradictions. The party, which struck a partnership agreement with Vladimir Putin's political party earlier in 2017, opposes the international sanctions regime against Russia, but nonetheless supported the sanctions at the EU level."11

The hard tone on migration and criticism of the Schengen zone or the free movement of people within the EU cannot be fully elaborated on, as the mainstream ÖVP had hardened its stance on these matters before the Austrian elections in 2017 (for the purposes of the electoral campaign with an idea to outflank the far-right FPÖ on those issues) — as a reminder, Sebastian Kurz was deeply involved in closing the migration route through the Western Balkans in the face of strong resistance from Angela Merkel. The FPÖ belongs, however, to the Euro-skeptic Europe of Nations and Freedom in the European Parliament; - according to Politico: "affiliation critics say it is inconsistent with a 'pro-European' philosophy. Here and then the FPÖ representatives show up on Euro-sceptic summits along with members of the French RN, the Dutch Party for Freedom or the Italian Lega." 12 The anti-EU slogans enjoy much popularity in their midst and shape the official discourse of FPÖ in interior politics; when it comes to Realpolitik and dayto-day governance, the FPÖ has never come up with a genuine proposal to curb the influence of the EU either at the Austrian or at the European level. It also proves that the populist erratic and emotional rhetorical drumbeat and the real political actions, as well as reality itself, remain contradictory. The far-right populist parties which are largely presented in the EU parliament are pursuing, and are in fact obliged to pursue, antagonistic interests if they do not want to submit to severe criticism in their respective countries. The FPÖ, like other nationalist, sovereigntist and Euro-skeptic parties on the right fringes, would have hardly initiated any common crusade against the European Union. According to the political observers and commentators of Politico:

Among the many issues that divide the right-wing populists are attitudes to Russia and economic policy. The Poles and Swedes are virulently anti-Putin whereas Salvini, Le Pen, Strache and Orbán are admirers of the Kremlin leader. The German and North European rightists are fiscally ultra-conservative while the French, Italian and Polish nationalists want to ignore EU budget discipline rules and boost social spending. ${ }^{13}$

The chasm between the anti-European populist narrative and political actions may epitomize the credibility (or lack thereof) of all far-right populist parties. Obviously, we can never be sure what would have happened if FPÖ had won the elections and had more power within a coalition government, or if more European

11 See: Austria's (not so) pro-European government, https://www.politico.eu/article/austriasnot-so-pro-european-government/ (accessed: 9.04.2020).

12 See: Ibidem.

13 See: Austria is no model for the EU, https://www.politico.eu/article/austria-bad-model-eufar-right-coalition/ (accessed: 9.04.2020). 
countries had followed this example. The most striking conclusion describing the FPÖ's stance on the European Union, which could be symptomatic for the populist parties all over Europe, once they are in power, comes from its former leader, H.-Ch. Strache: "We view one or the other position critically and have different positions that we will naturally articulate and look for partners on. That's the democratic game." 14 This is like populism itself, which leads us back to Ernesto Laclau.

\section{Conclusion}

The far-right populist stance on EU matters, demonstrated by the example of the Austrian Freedom Party, is not unequivocal, but instead shows more contradictory and versatile traits. The official discourse complies with the ideological foundations of right-wing or extreme right political groups; it depicts the European Union as a threat to national independence and sovereignty, whereas EU officials and pro-European political opponents are described as the enemies of 'ordinary people'. This perception results from political messages, filled with emotional and vituperative language, the aim of which is to appeal to a specific electorate or to impose a distorted political vision. It is after all the rhetoric - a dexterous conceptualized use of language - that attracts potential voters. The EU-orientated discourse of the FPÖ exemplifies the populist strategy of achieving political goals; it adapts itself to dynamic social changes, puts them verbally into a desired direction, manipulates facts and amplifies strong emotions. The European integration, along with globalization, has left/is leaving long-lasting traces in the society and economy of each member state; it has profoundly remodeled previous economic and social structures. The populists who exploit those changes in a verbally radical way are plainly one of many responses being spoken aloud in the democratic game. The real political actions taken by populist parties, however, do not necessarily follow the words. The almost two years' co-governance by the Austrian Freedom Party illustrates the complexity of the approach of far-right populism towards the EU; the once outspoken antagonistic rhetoric was not put into action, but remained audible merely for demagogic purposes, whereas FPÖ leaders profited from being in governmental positions without challenging the status quo of the Austrian cooperation with what they called 'Brussels' system.' The scenario for an ongoing cooperation could obviously have been different in the long term; however, it is rather impractical to unilaterally deprecate the ambivalent attitude shown by the FPÖ towards a unified Europe. In politics, nothing is clear; current political developments are a rather an outcome of democratic games, of which populism and the Austrian Freedom Party are a substantial part.

14 See: Austria's (not so) pro-European... 


\section{Bibliography}

25 Jahre EU-Mitgliedschaft Österreichs - eine Bilanz aus wirtschaftlicher Perspektive, https:// oegfe.at/2019/12/25-jahre-mitgliedschaft-wirtschaft/.

Austria is no model for the EU, https:/www.politico.eu/article/austria-bad-model-eu-far-right-co alition/.

Austria's FPÖ Freedom Party: A turbulent history, https://www.dw.com/en/austrias-fp\%C3\%B6freedom-party-a-turbulent-history/a-48789817.

Austria's (not so) pro-European government, https://www.politico.eu/article/austrias-not-so-proeuropean-government/.

Buti M., Pichelmann K., European Integration and populism: Addressing Dahrendorf's quandary, https://ec.europa.eu/info/sites/info/files/jan2017-populism.pdf.

Dahrendorf R., Economic Opportunity, Civil Society and Political Liberty, https://www.unrisd. org/80256B3C005BCCF9/(httpAuxPages)/AF2130DF646281DD80256B67005B66F9/\$file/ DP58.pdf.

Der Mann, der den modernen Rechtspopulismus erfand, https:/www.sueddeutsche.de/politik/10todestag-von-joerg-haider-der-mann-der-den-modernen-rechtspopulismus-erfand-1.4156739.

Eurobarometer - Umfrage: Höchste Unterstützung für die EU seit 35 Jahren, https://www.euro parl.europa.eu/news/de/headlines/eu-affairs/20180522STO04020/eurobarometer-umfragehochste-unterstutzung-fur-die-eu-seit-35-jahren.

Greven T., The rise of Right-Wing Populism in Europe and the United States - a comparative perspective, https://www.fesdc.org/fileadmin/user_upload/publications/RightwingPopulism.pdf.

Laclau E., On populist reason, London-New York 2005.

Mehr Österreich, weniger EU, https://www.fpoe.eu/mehr-oesterreich-weniger-eu/.

On populist reason by Ernesto Laclau, reviewed by James Hodgson, https://marxandphilosophy. org.uk/reviews/16457_on-populist-reason-by-ernesto-laclau-reviewed-by-james-hodgson/. 